\title{
The Prognostic Impact of the Neutrophil-Lymphocyte Ratio in Small-Cell Lung Cancer
}

\section{Küçük Hücreli Akciğer Kanserinde Nötrofil-Lenfosit Oranının Prognostik Önemi}

\author{
Mustafa Altınbaş ${ }^{1}$, Mevlüde İnanç ${ }^{2}$, Cengiz Karaçin ${ }^{3}$ \\ ${ }^{1}$ Sağlık Bilimleri Üniversitesi, Dışkapı Yıldırım Beyazıt Eğitim ve Araştırma Hastanesi, Tıbbi Onkoloji Kliniği, \\ Ankara, Türkiye \\ ${ }^{2}$ Erciyes Üniversitesi Tıp Fakültesi, Tıbbi Onkoloji Kliniği, Kayseri, Türkiye \\ ${ }^{3}$ Sağlık Bilimleri Üniversitesi, Dr Abdurrahman Yurtaslan Onkoloji Eğitim ve Araştırma Hastanesi, Tıbbi \\ Onkoloji Kliniği, Ankara, Türkiye
}

\section{ÖZET}

GİRIŞ ve AMAÇ: Son dönemde immünoterapilerin sağkalıma küçük bir katkısı olsa da küçük hücreli akciğer kanserinde halen yeni tedavilere ihtiyaç vardır. Bu çalışmada, küçük hücreli akciğer kanserinde (KHAK) bilinen prognostik faktörlere ek olarak bir sistemik inflamatuar indeks olan nötrofil-lenfosit oranının (NLO) prognostik öne $\neg$ mini göstermeyi amaçladık.

YÖNTEM ve GEREÇLER: Toplam 203 KHAK'li hasta retrospektif olarak değerlendirildi. Hastaların demografik bilgileri, tedavi rejimleri, hastalık progresyon ve eksitus tarihleri hastane otomasyon sisteminden veya hasta dosyalarından elde edildi. Genel sağkalımı (OS) etkileyen faktörler tek değişkenli analizle saptandıktan sonra bağımsız prognostik faktörlerin tespiti için çok değişkenli Cox regresyon analizi yapıldı.

BULGULAR: Ortalama yaş 58 $\pm 9,3$ idi. Hastaların \%91,6'sı erkek idi. Hastaların \%64,5'i yaygın hastalık evresindeydi. En sık uygulanan kemoterapi rejimi cisplatin + etoposid, ortanca kür sayısı 6 idi. Objektif yanıt oranı (ORR) \%65,7 idi. Çok değişkenli Cox regresyon analizi sonucunda yaygın hastalık evresi, ileri yaş ( $\geq 65)$, yüksek NLO ( $\geq 5)$ ve yüksek LDH düzeyi ( $\geq 550)$ OS için bağımsız kötü prognostik faktörler olarak tespit edildi.

TARTIŞMA ve SONUÇ: NLO’nun genel sağ kalımı (OS) etkileyen bağımsız prognostik faktörlerden biri olabileceği gösterildi.

Anahtar Kelimeler: Nötrofil-lenfosit oranı (NLO), Prognostik faktör, Küçük hücreli akciğer kanseri (KHAK), Sağkalım

ABSTRACT
INTRODUCTION: Although immunotherapies have made a small contribution to survival in recent years, there is a need for new treatments for small cell lung cancer (SCLC). We aimed to show the prognostic importance of the neutrophil-lymphocyte ratio (NLR), which is a systemic inflammatory index, in addition to the known prognostic factors in SCLC in this study.

METHODS: We retrospectively evaluated a total of 203 SCLC patients. Demographic data, treatment regimes, disease progression and date of exitus were retrieved from patient files and the hospital automated records system. After the determination of factors affecting overall survival (OS) with univariate analysis, Cox regression model was performed to demonstrate the prognostic factors affecting OS.

RESULTS: The patients comprised $91.6 \%$ males and $8.4 \%$ of females with a mean age of $58 \pm 9.3$ years. Onehundred-thirty-one $(64.5 \%)$ patients had extensive-stage disease. The most frequently applied chemotherapy regime was cisplatin+etoposide, with a median of 6 cycles. The objective response rate (ORR) was $65.7 \%$. As a result of Cox regression analysis, the extensive-stage disease, advanced age ( $\geq 65$ years), high NLR ( $\geq 5)$, and high LDH level ( $\geq 550)$ were determined to be independent poor prognostic factors for OS.

DISCUSSION AND CONCLUSION: The results of the study showed that high NLR has negative impact on OS in patients with SCLC.

Keywords: Neutrophil-lymphocyte ratio (NLR), Prognostic factor, Small cell lung cancer (SCLC), Survival 


\section{INTRODUCTION}

Lung cancer is one of the most frequently seen cancers throughout the world (1). Small cell lung cancer (SCLC) shows different biological behavior than other histopathological types and responds well to chemotherapy(1).However, resistance to treatment develops after a short time and the disease progresses(1).With the usage of immunotherapy and chemotherapy (CT) combinations in extensive-stage disease, an advantage has been obtained of approximately 2 months in overall survival (OS) compared to CT alone (2). Nevertheless, the median OS has not exceeded 12 months (2).

Limited-stage disease, ECOG performance status of $0-1$, female gender, absence of brain metastasis at the time of diagnosis, no dose reduction in chemotherapy and normal serum LDH values have been determined as independent good prognostic factors determining OS in SCLC patients (3-5). A high complete response rate and a long duration of response time to progression are markers of good prognosis in SCLC patients (6).Smoking has a negative effect on OS(4) with significantly lower survival reported for smokers compared to non-smokers (7). An advantage of 9 months OS has been reported for non-smokers compared to patients who smoke (7).

The prognostic importance of systemic inflammatory response has been shown in several cancer types $(8,9)$. Laboratory markers of systemic inflammation include a high $\mathrm{C}$ reactive protein (CRP), hypoalbuminemia, neutrophilia, thrombocytosis, and lymphopenia. Previous studies have also shown that the neutrophil-lymphocyte ratio (NLR), as another systemic inflammatory marker, could be used as a prognostic factor in lung cancer, just as it is in other cancer types(10-13). The majority of studies on this subject have been conducted on patients with non-small-cell lung cancer (NSCLC), and there are very few studies with a limited number of patients that have been conducted on SCLC patients (10-15). Therefore, we aimed to demonstrate the prognostic importance of NLR in a large SCLC populationin this multicentric study.

\section{MATERIAL METHOD}

The presented study was approved by the ethics committee of the Erciyes University Faculty of Medicine. We retrospective reviewed a total of 203 patients with SCLC between February 2005 and February 2018 in Diskapi Yildirim Beyazit Training and Research Hospital and Erciyes University Faculty of Medicine Hospital. The patients included were aged $\geq 18$ years with a histopathologically confirmed diagnosis with SCLC. Patients were excluded if they had a previously known diagnosis of non-small cell lung cancer, if mixed cancer cells (non-small cell) were determined in the histopathological diagnosis, if they withdrew from follow-up during the treatment period or if data were not available.

Data were obtained from the patient files and hospital automated system and were added to the database, including age, gender, disease stage, treatment regimes applied and durations, hemogram (neutrophil count, lymphocyte count), serum lactate dehydrogenase (LDH), coagulation parameters, date of disease progression, exitus or final follow-up examination. The OS of all the patients was calculated, defined as the time from diagnosis to death of any cause. The NLR was calculated as the neutrophil absolute count divided by the total lymphocyte count.

\section{Statistical Analysis}

Statistical analysis were done via IBM SPSS vn. 20 software. Parametric variables were stated as mean \pm standard deviation (SD) values and nonparametric variables as median (range). In the determination of factors affecting 
survival, ROC analysis was applied to determine the optimal cutoff values in respect of age and laboratory values. In the survival analyses, the Kaplan-Meier survival analysis was used, and Cox Regression analysis was used to demonstrate the independent prognostic factors affecting survival. All the analyses were made two-way and a value of $\mathrm{p}<0.05$ was accepted as statistically significant.

\section{RESULTS}

The patients comprised $91.6 \%$ males and $8.4 \%$ of females with a mean age of $58 \pm 9.3$ years. One-hundred-thirty-one $(64.5 \%)$ patients had extensive-stage disease. The most common metastatic site was the liver. The most frequently applied chemotherapy regimen was cisplatin+etoposide, with a median of 6 cycles. The objective response rate (ORR) in a total of 198 treated patients was $65.7 \%$ (Table 1).

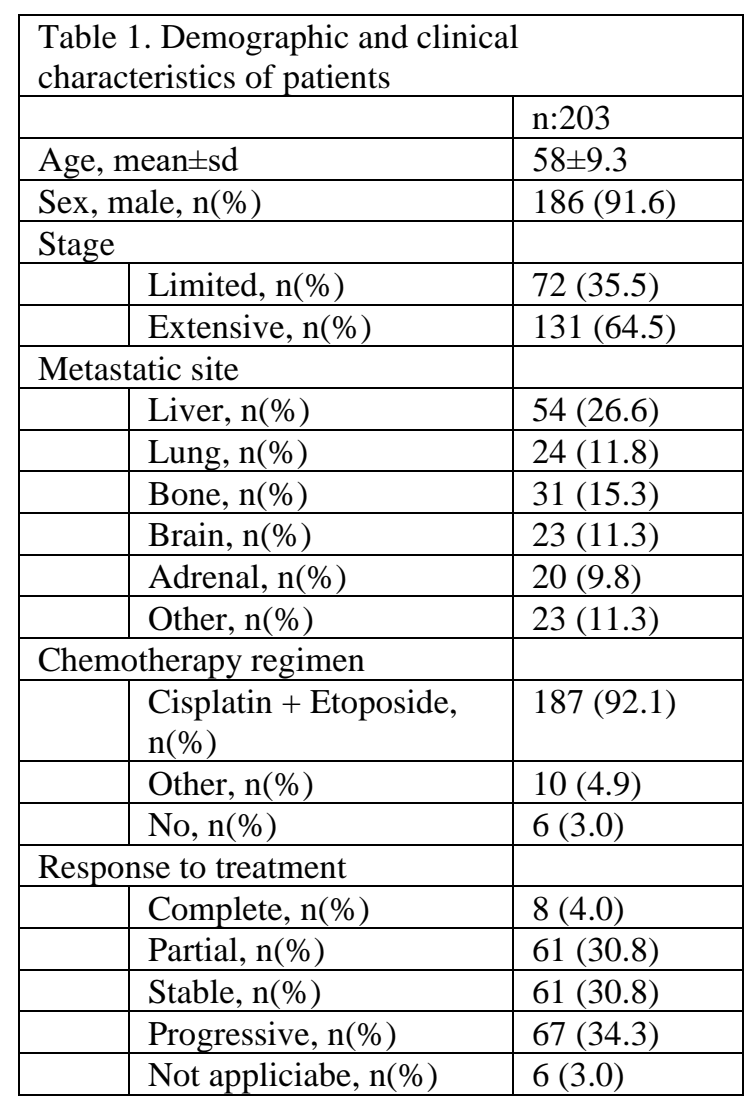

The median follow-up period was 9 months (range, 1-107 months). The median OS of the whole patient group was 9 months $(95 \%$ CI, 7.8-10.1 months). A total of 190 (93.5\%) patients died due to SCLC. The result of the univariate survival analysis of factors affecting

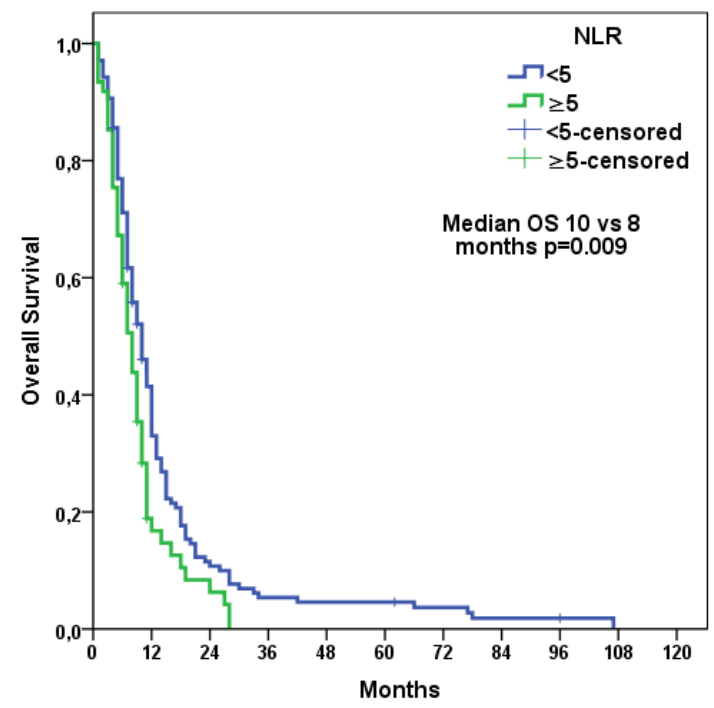

Figure 1: Overall survival according to neutrophilelymphocyte ratio

OS are shown in Table 2. In patients with the extensive-stage disease, advanced age, high neutrophil count, high NLR or high LDH, OS was shorter. The median OS of patients with $\mathrm{NLR} \geq 5$ was 8 months (range, 6.3-9.6 months) and for those with NLR $<5$, median OS was 10 months (range 8.2-11.7 months) ( $\mathrm{p}=0.009$ ) (Fig. $1)$.

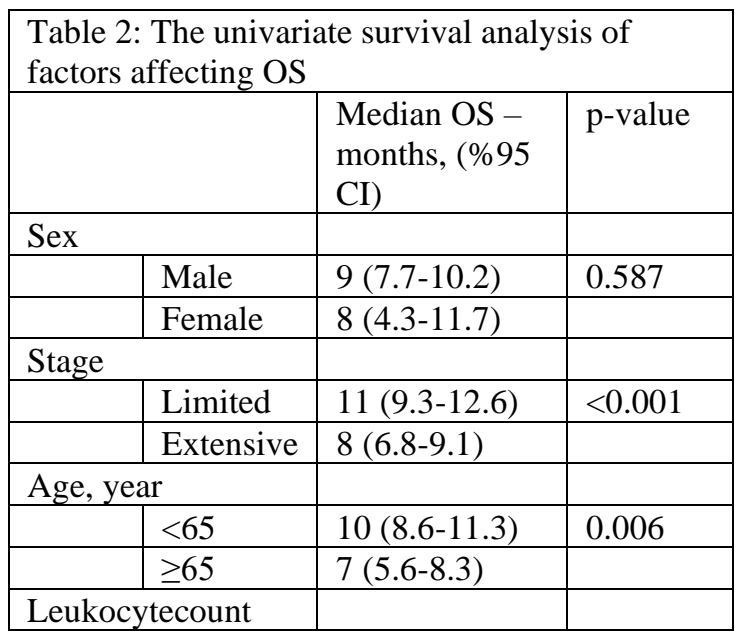




\begin{tabular}{|c|c|c|c|}
\hline & $<11000$ & $9(7.6-10.4)$ & 0.069 \\
\hline & $\geq 11000$ & $8(6.1-9.8)$ & \\
\hline \multicolumn{4}{|c|}{ Neutrophilcount } \\
\hline & $<7000$ & $10(8.1-11.8)$ & 0.009 \\
\hline & $\geq 7000$ & $7(5.1-8.8)$ & \\
\hline \multicolumn{4}{|c|}{ Lymhocytecount } \\
\hline & $<2000$ & $9(7.7-10.2)$ & 0.189 \\
\hline & $\geq 2000$ & $8(6.2-9.7)$ & \\
\hline \multicolumn{4}{|l|}{ NLR } \\
\hline & $<5$ & $10(8.2-11.7)$ & 0.009 \\
\hline & $\geq 5$ & $8(6.3-9.6)$ & \\
\hline \multicolumn{4}{|l|}{ LDH } \\
\hline & $<550$ & $10(8.6-11.3)$ & 0.001 \\
\hline & $\geq 550$ & $7(5.8-8.2)$ & \\
\hline $\begin{array}{l}\text { Abbre } \\
\text { Confic } \\
\text { lymho }\end{array}$ & $\begin{array}{l}\text { ons: OS } \\
\text { e interv } \\
\text { ratio; L }\end{array}$ & $\begin{array}{l}\text { erall surviva } \\
\text { ILR, Neutrop } \\
\text { lactate dehy }\end{array}$ & \\
\hline
\end{tabular}

$\mathrm{p}=0.019)(14)$. Although NLR was seen to be higher in patients with the extensive-stage disease compared to those with the limitedstage disease, multivariate analysis showed that high NLR had negative impact on survival independent of disease stage (HR:1.46, $\mathrm{p}=0.043$ ) (14). Similarly in the current study, OS was shorter in patients with high NLR $(\geq 5)$ compared to those with low NLR (8 vs 10 months, $\mathrm{p}=0.009)$. The results of multivariate analysis also showed that high NLR was an independent poor prognostic factor (HR: 1.06, $\mathrm{p}<0.001)$. Wang et al found that high NLR $(\geq 3)$ was related to poor prognosis only in SCLC with mixed histopathology diagnosis (HR:1.70, $\mathrm{p}=0.030$ ), and NLR did not show prognostic importance in pure SCLC (15). Therefore, because of the differences between these studies, there is a need for additional studies to be able to show the prognostic importance of NLR in SCLC.

Table 3. Multivariate Cox regression analysis to determine independent prognostic factors affecting OS

\begin{tabular}{|l|l|l|l|l|}
\hline & OS & \multicolumn{4}{l|}{} \\
\hline & & \multicolumn{4}{l|}{ Confidenceinterval(CI \%95) } & \\
\hline & HR & Lower limit & Upper limit & p-value \\
\hline Stage $($ Extensive vs limited) & 1.53 & 1.11 & 2.11 & $\mathbf{0 , 0 0 9}$ \\
\hline Age $(\geq 65$ vs $<65)$ & 1.03 & 1.02 & 1.05 & $<\mathbf{0 . 0 0 1}$ \\
\hline Leukocytecount $(\geq 11000$ vs $<11000)$ & 1.00 & 1.00 & 1.00 & 0.376 \\
\hline Neutrophilcount $(\geq 7000$ vs $<7000)$ & 0.98 & 0.92 & 1.05 & 0.675 \\
\hline Lymphocyte count $(<2000$ vs $\geq 2000)$ & 1.22 & 0.93 & 1.61 & 0.139 \\
\hline NLR $(\geq 5$ vs $<5)$ & 1.06 & 1.02 & 1.09 & $\mathbf{0 . 0 0 1}$ \\
\hline LDH $(\geq 550$ vs $<550)$ & 1.02 & 1.01 & 1.03 & $\mathbf{0 . 0 4 3}$ \\
\hline Abbrevact
\end{tabular}

Abbrevations: OS, Overall survival; CI, Confidence interval; NLR, Neutrophil-lymhocyte ratio; LDH: lactate dehydrogenase.

\section{DISCUSSION}

We aimed to investigate the prognostic importance of NLR in SCLC. The results of the study demonstrated that NLR was an independent prognostic factor in addition to disease stage, age, and LDH level.

In a study of 187 SCLC patients by Kang et al, NLR was shown to be an independent prognostic factor, and OS was shorter in those with NLR $\geq 4$ compared to those with NLR <4 (median OS: 9.2 vs. 11.1 months,
Previous studies have shown that NLR is not only prognostic but can also be used as a predictive marker $(16,17)$. In a study of NSCLC patients treated with nivolumab, Diem et al showed that NLR could predict the response to treatment and in those with NLR $>5$, OS was shorter than those with NLR $<5$ (NLR corresponding to 5.1 months, $\mathrm{p}=0.013$ ) (16). Similar results were shown in patients with malignant melanoma (17).Capone et al reported that malignant melanoma patients who had NLR $\geq 5$ at the time of diagnosis had worse survival (17). As the use of immunotherapies in 
SCLC is still not widespread, the predictive importance of NLR is still not known.

In a study that used atezolizumab in combination with CT in SCLC, longer survival was obtained in the combination arm compared to the only CT arm(2). When the subgroup analyses were evaluated there was seen to be a survival advantage especially in patients aged $>65$ years and in those with ECOG performance status of 1(2). Age and ECOG performance status are known to be prognostic markers in SCLC(4). From this point, it was thought that as NLR was shown to be a prognostic marker in the current study, it could have predictive importance in patients applied with immunotherapy, and studies could be designed on this subject.

Li et al showed that extensive stage disease had a significant negative effect on survival(5). As a result of multivariate analysis, the extensive-stage disease was shown to be a poor prognostic factor (5). In a retrospective study by Wahba et al, similar results were obtained (4). Brueckl et al reported longer survival in those with the limited-stage disease compared to those with the extensive-stage disease (3). As expected, we showed that patients with extensive-stage disease had shorter OS. This result was attributed to the higher tumor load in the extensive-stage disease.

In a study by Wahba et al, advanced age was found to be related to a poor prognosis for SCLC(4). OS was determined to be significantly shorter for patients aged $\geq 65$ years compared to those $<65$ years $(\mathrm{p}=0.03)$ (4). In a study by Bremnes et al, no difference was determined between patients older and younger than 65 years in respect of OS (18). Similar to the Wahba et al study, older age was associated with poor prognosis in the current study, with OS determined as 7 months in patients aged $\geq 65$ years and 10 months in $<65$ years $(\mathrm{p}=0.006)$. In a retrospective study of 106 patients by Brueckl et al, elevated LDH was found to be related to non-response to treatment in SCLC (3). Wahba et al obtained similar results and as a result of multivariate analysis, a high LDH level was shown to be a poor prognostic factor(4).Similarly, Bremnes et al reported that an LDH level of $\geq 540$ significantly shortened survival (18).In the current study, OS was seen to be shorter in patients with $\mathrm{LDH} \geq 550$ (7 months vs. 10 months, $\mathrm{p}=0.001$ ).

There were some limitations to this study. As factors such as corticosteroid use and infection, which could affect neutrophil and lymphocyte counts, were not taken into consideration, this could have affected the results of the analyses. In addition, there was insufficient data about smoking, so the factor of smoking could not be added to the survival analyses. Finally, as there was a lack of information about side-effects related to the chemotherapy applied and post-treatment tests, the effect on survival of changes in neutrophil and lymphocyte counts and the NLR could not be shown in this study.

\section{CONCLUSION}

The results of this study showed that NLR, which is a simple, inexpensive and readily available test that can be calculated from a hemogram, can be used as a prognostic marker in SCLC. There is a need for additional validation studies to determine the optimal cutoff value for NLR.

Acknowledgements The authors thank all participants of the study.

Funding: The authors report no sponsorship or funding.

Conflict of interest : The authors declare that they have no confict of interest. 


\section{References}

1. Bernhardt EB, Jalal SI. Small Cell Lung Cancer. Cancer Treat Res. 2016;170:301-22.

2. Horn L, Mansfield AS, Szczesna A, et al. First-Line Atezolizumab plus Chemotherapy in Extensive-Stage Small-Cell Lung Cancer. N Engl J Med. 2018;379:222029.

3. Brueckl WM, Herbst L, Lechler A, et al. Predictive and prognostic factors in small cell lung carcinoma (SCLC)analysis from routine clinical practice. Anticancer Res. 2006;26:4825-32.

4. Wahba HA, El-Hadaad HA, Anter AH, Ahmad MA-S, Ghazy HFA-EH. Outcomes and Prognostic Factors of Small Cell Lung Cancer: A Retrospective Study. Advances in Lung Cancer. 2018;7:21-31.

5. Li J, Dai C-H, Chen P, et al. Survival and prognostic factors in small cell lung cancer. Med Oncol. 2010;27:7381.

6. Sedef AM, Çalikuşu Z, Bahçeci A, Gökçay S, Sümbül AT. The Prognostic Significance of Complete Response Rates in Patients with Extensive Stage Small Cell Lung Cancer. Turkish Journal of Oncology. 2019;34:45-8.

7. Chen J, Jiang R, Garces YI, et al. Prognostic factors for limited-stage small cell lung cancer: a study of 284 patients. Lung Cancer. 2010;67:221-26.

8. Hizal M, Sendur MA, Yasar HA, et al. Neutrophillymphocyte ratio as a prognostic factor for survival in patients with advanced renal cell carcinoma (Turkish Oncology Group Study). J Oncol Pharm Pract. 2020:1078155219900908.

9. Imamoglu GI, Eren T, Baylan B, Karacin C. May High Levels of Systemic Immune-Inflammation Index and Hematologic Inflammation Markers Suggest a Further Stage in Testicular Tumours? Urol Int. 2019;103:303-10.

10. Sarraf KM, Belcher E, Raevsky E, Nicholson AG, Goldstraw P, Lim E. Neutrophil/lymphocyte ratio and its association with survival after complete resection in nonsmall cell lung cancer. The Journal of thoracic and cardiovascular surgery. 2009;137:425-28.

11. Unal D, Eroglu C, Kurtul N, Oguz A, Tasdemir A. Are neutrophil/lymphocyte and platelet/lymphocyte rates in patients with non-small cell lung cancer associated with

Adress for correspondence:

e-mail: cengizkaracin@yahoo.com

Available at www.actaoncologicaturcica.com

Copyright $\mathbb{C}$ Ankara Onkoloji Hastanesi treatment response and prognosis? Asian Pac J Cancer Prev. 2013;14:5237-42.

12. Pinato D, Shiner R, Seckl M, Stebbing J, Sharma R, Mauri F. Prognostic performance of inflammation-based prognostic indices in primary operable non-small cell lung cancer. Br J Cancer. 2014;110:1930-35.

13. Cannon NA, Meyer J, Iyengar P, et al. Neutrophillymphocyte and platelet-lymphocyte ratios as prognostic factors after stereotactic radiation therapy for early-stage non-small-cell lung cancer. J Thorac Oncol. 2015;10:28085.

14. Kang MH, Go S-I, Song H, et al. The prognostic impact of the neutrophil-to-lymphocyte ratio in patients with smallcell lung cancer.Br J Cancer. 2014;111:452-60.

15. Yin Y, Wang J, Wang X, et al. Prognostic value of the neutrophil to lymphocyte ratio in lung cancer: a metaanalysis. Clinics. 2015;70:524-30.

16. Diem S, Schmid S, Krapf M, et al. Neutrophil-toLymphocyte ratio (NLR) and Platelet-to-Lymphocyte ratio (PLR) as prognostic markers in patients with nonsmall cell lung cancer (NSCLC) treated with nivolumab. Lung Cancer. 2017;111:176-81.

17. Capone M, Giannarelli D, Mallardo D, et al. Baseline neutrophil-to-lymphocyte ratio (NLR) and derived NLR could predict overall survival in patients with advanced melanoma treated with nivolumab. J Immunother Cancer. 2018;6:74.

18. Bremnes RM, Sundstrom S, Aasebø U, et al. The value of prognostic factors in small cell lung cancer: results from a randomised multicenter study with minimum 5 year follow-up. Lung Cancer. 2003;39:303-13. 